\title{
TURISMO E DINÂMICAS TERRITORIAIS: ORGANIZAÇÃO E INFLUÊNCIA DAS ATIVIDADES TURÍSTICAS EM MARRACUENE- MOÇAMBIQUE
}

\author{
TOURISM AND TERRITORIAL DYNAMICS: ORGANIZATION AND INFLUENCE OF TOURIST ACTIVITIES IN \\ MARRACUENE- MOZAMBIQUE
}

\section{RESUMO}

Este artigo visa analisar a influência das atividades turísticas sobre o distrito de Marracuene em Moçambique, tendo a praia de Macaneta como indutor deste processo. O objetivo principal é pontuar como o turismo vem se estruturando na praia de Macaneta, bem como os desdobramentos que que acompanham esse processo. Constatamos que o turismo tem influenciado nas dinâmicas territoriais de Marracuene, como também verificamos que as próprias atividades turísticas têm resultado em transformações tanto na estrutura organizacional do turismo quanto nas relações que são estabelecidas. A metodologia utilizada para o levantamento de dados está pautada na oralidade e na observação, pois foram realizadas entrevistas semiestruturadas com alguns moradores, bem como em instituições locais públicas. Foi possível perceber que grande parte das transformações em curso nesse território, estão direcionadas a atrair turistas, pois para que essa atividade possa crescer e se estruturar, ela tem que atender aos requisitos do turista atual, que busca além de lugares exuberantes e lazer, a comodidade.

Palavras-chave: Território; Turismo; Marracuene, Moçambique

\section{ABSTRACT}

This article aims to analyze the influence of tourist activities on the Marracuene district in Mozambique, having Macaneta beach as an inductor of this process. The main objective is to point out how tourism has been structured on Macaneta beach, as well as the unfolding that have accompanied this process. We found that tourism has influenced the territorial dynamics of Marracuene, as well as that the tourism activities themselves have resulted in changes both in the organizational structure of tourism and in the relationships that are established. The methodology used for data collection is based on orality and observation, as semi-structured interviews were conducted with some residents, as well as local, public institutions. It was possible to realize that a large part of the transformations taking place in this territory are aimed at attracting tourists, because in order for this activity to grow and be structured, it has to meet the requirements of the current tourist, who seeks beyond exuberant places and leisure, the comfort.

Keywords: Territory; Tourism; Marracuene, Mozambique.
(iD Karoline Batista Gonçalves (D) Lucas Atanásio Catsossa ${ }^{\mathrm{b}, \mathrm{c}}$

${ }^{\text {a }}$ Universidade Federal da Grande Dourados (UFGD), Dourados, MS, Brasil ${ }^{b}$ Universidade Púnguè (UniPúnguè), Tete, Moçambique c Universidade Católica de Moçambique (UCM), Tete, Moçambique

DOI: 10.12957/geouerj.2020.53919

Correpondência: estiloartesc@hotmail.com

Recebido em: 29 nov. 2019 Revisado em: 11 fev. 2020 Aceito em: 4 mai. 2020 
Moçambique é um país parte da África Austral, com características e elementos muito particulares, capaz de fascinar aqueles que se dispõem a viver uma experiência em suas terras. A capital moçambicana chama-se Maputo e, é onde atualmente, se observam várias transformações socioespaciais, caracterizadas pela emergência de novas infraestruturas que, com certeza, terão grande importância na dinamização do setor turístico do país. Territorialmente, a organização administrativa de Moçambique compreende províncias, distritos, postos administrativos e localidades.

Os dados do último censo populacional realizado em 2017, indicam que Moçambique tem uma população extimada em cerca de 27909 798, sendo que deste número, 13348446 são homens e 14561352 são mulheres. Importa realçar que, a maior parte da população moçambicana vive no meio rural quando comparada com a que vive nas cidades, sendo $66,6 \%$ e $34,4 \%$ respectivamente (cf. INE, 2017). Diante disso, o presente artigo tem como objetivo aprofundar suas análises partindo do distrito de Marracuene. Durante a realização dos trabalhos de campo, foi possível observar e pontuar como o turismo moçambicano está se estruturando no mesmo, que tem a peculiaridade de estar localizado próximo a capital, na província de Maputo.

A metodologia utilizada para o levantamento de dados está pautada na oralidade, pois foram realizadas entrevistas semiestruturadas com alguns moradores, bem como instituições locais públicas. Através das entrevistas foi possível obter informações que possibilitaram compreender como as atividades turísticas interferem e modificam o território. Por sua vez, foi possível compreender como influenciam também no modo de vida das populações do distrito de Marracuene.

\section{Território e territorialidade: uma abordagem conceitual}

Na Geografia Humana, Território e Turismo são conceitos indissociáveis, pois ambos se intercambiam mutuamente. Por isso, para a compreensão do processo de produção do espaço turístico, torna-se importante dialogar com o conceito do território. Ao longo dos anos a categoria território tem adquirido uma grande importância no que diz respeito analisar o ato do sujeito em busca de uma ordem e de uma organização do espaço. De alguma maneira a ideia de território está ligada a identidade, ou seja, aos laços que são construídos com ele, e proporcionam um referencial.

Diante disso, torna-se importante dialogar com o conceito deste para compreender a identidade, a mobilidade, a organização e a complexidade presentes no território moçambicano. Em conformidade com Raffestin (2015, p. 22), é essencial compreender que o espaço está em posição que antecede o território, porque este é gerado a partir do espaço, ele é o "resultado de uma ação conduzida por um ator que realiza 
um programa de qualquer nível". Logo, o autor salienta que "apropriando-se concretamente ou abstratamente de um espaço o ator o territorializa" (RAFFESTIN, 2015, p. 22).

Nessa perspectiva, entendemos que para se produzir um território é necessário que o sujeito projete no espaço algum tipo de trabalho, que será adaptado as condições de vivência em sociedade. Assim, o território transforma-se de acordo com os ritmos das novas técnicas e as relações que vão sendo estabelecidas, visto que "cada civilização é caracterizada por sistemas compostos diversamente ou situados em diferentes níveis de desenvolvimento" (RAFFESTIN, 2015, p. 22). Na maioria dos casos, o que define um território são as relações de poder. No entanto, outras relações de cunho cultural e/ou econômica podem ser fortemente identificadas na formação do território. Dessa forma, podemos pensar que o território é um produto das mudanças que ocorrem em uma determinada sociedade. A esse respeito, Saquet (2015) afirma que:

Território significa apropriação social do ambiente; ambiente construído, com múltiplas variáveis e relações recíprocas. $O$ homem age no espaço (natural e social) de seu habitar, produzir, viver, objetiva e subjetivamente. O território é um espaço natural, social, historicamente organizado e produzido; a paisagem é o nível visível e percebido deste processo. O território é produto de ações históricas que concretizam em momentos distintos e sobrepostos, gerando diferentes paisagens (SAQUET, 2015, p. 77).

Por isso, entendemos que a forma como o sujeito se organiza em um determinado espaço, e a maneira como ele vive e o uso dado ao mesmo, acaba produzindo um território, e nisso podemos acrescentar que ele é um produto das ações históricas que vão se desenvolvendo. Na medida em que, o território é apropriado e produzido as relações que vão se estabelecendo acabam ficando em movimento, e passam a ser influenciadas ou muitas vezes reconstruídas espacialmente e temporalmente conforme a intensidade das relações. Na organização do território Saquet (2011) enfatiza que existem mudanças sociais que se substantivam em rearticulações e redefinições, em novas relações estabelecidas entre os sujeitos que acabam combinando o local com o global resultando na conexão e integração entre diferentes lugares e sujeitos.

Partindo desses apontamentos, é importante entender a territorialidade, que pode inicialmente ser vista como uma dimensão social das relações cotidianas e da apropriação e produção do território. Em relação à territorialidade Saquet (2011) evidencia que o conceito de territorialidade pode ter distintos significados e interpretações, conforme a abordagem proposta. E essas interpretações podem englobar desde o sentido de entender territorialidade como um chão e/ou recorte espacial, passando pela atuação do Estado-nação até a compreensão das relações de poder: 
A territorialidade significa essas relações cristalizadas entre os sujeitos e destes com o seu lugar de vida. Os indivíduos interagem, de modo espacial, cultural e economicamente, e são essas relações que se condicionam que corresponde a territorialidade ou às territorialidades. A territorialidade corresponde a todas as relações sociais efetivadas pelos sujeitos entre si e com o espaço de vida; é marcada por elementos de mudanças e processos no movimento de territorialização que, por sua vez gera o território. A territorialidade corresponde às dimensões sociais do território, ou seja, às relações econômicas, políticas e culturais que os homens estabelecem entre si e com a natureza exterior, a territorialidade é relacional e significa relações de poder, redes de circulação e comunicação, identidades, dominação social, resistências, conflitos entre outros componentes que indicam relações sociais entre os sujeitos e entre esses com seu lugar de vida (SAQUET, 2011, p. 45-46).

Nesse sentido, fica claro evidenciar a territorialidade como os laços que vão sendo construídos com o território, ou seja, ela é o resultado da apropriação e da construção do território manifestada através das relações sociais de dominação do próprio território. Tanto a concepção de território quanto a territorialidade são de grande importância para observar à organização do turismo no território moçambicano, bem como as vivências, as relações entre os sujeitos e os referenciais identitário resultantes das relações estabelecidas entre culturas e sujeitos diferentes. Sabemos que cada território possui tempos históricos diferentes, os ritmos de vida as relações estabelecidas, enfim todo esse conjunto de fatores acaba influenciando na formação da territorialidade.

Sendo, assim, ela pode ser vista como uma mediação simbólica que a relação com o território implica sobre as relações sociais. A territorialidade pode tanto englobar indivíduos do mesmo grupo, ou as relações destes com distintos grupos sociais, nesse caso ela está fundada nas referências do lugar, e pode sofrer influências das condições históricas e geográficas. Para entender a construção da territorialidade moçambicana partimos das considerações de Saquet (2011) que dialoga com a ideia de que os processos sociais e territoriais não flutuam sobre os mares, montanhas e planícies, mas realizam-se pela unidade ideiamatéria-espaço-tempo no nosso cotidiano, e são os processos e os conceitos de território e territorialidade devem ser repensadas a partir de cada objeto e problemática.

\section{Produção, estrutura e organização do turismo em Moçambique}

O turismo é uma das atividades econômicas de Moçambique e, a geografia do turismo moçambicana é complexa, sobretudo, quando analisada cientificamente. Esta área do conhecimento científico, envolve questões políticas, econômicas, sociais, culturais, ambientais dentre outras. São essas questões que fazem com que o turismo seja uma das atividades mais complexas de ser compreendida em Moçambique. Mas, vale ressaltar que a maior parte dos lugares turísticos do país, estão na gestão privada. Algumas praias e áreas de conservação (parques e reservas) estão sendo geridos pelas empresas estrangeiras, dentre elas: sul-africanas e norte-americadas. $O$ governo tem alegado a falta de capacidade na gestão por parte do setor público, daí 
surge a justificativa para que as áreas de conservação sejam entregues e geridas por quem pode e tem capacidade e/ou condições.

Somado a isto, o governo em representação do Estado tem avançado em fazer a concessão de determinadas áreas de conservação para o setor privado. Significa que, o setor privado é que tem se beneficiado com as políticas governamentais. Algumas praias também foram entregues a gestão privada, outras, estão em via de privatização, e muitas vezes são fragmentadas e, mais tarde, são ocupadas pelas empresas turísticas, através de um esquema pouco conhecido. Igualmente, esse cenário tem acontecido com áreas de conservação da biodiversidade, no qual grande parte destas estão sendo gerenciadas por instituições privada, com excessão do Parque Nacional de Magoé, na província de Tete, estudado por Catsossa (2019).

Tomando como análise o discurso político que diz, por exemplo, “a gestão privada é mais eficiente quando compara com a gestão pública", existem fortes indícios que o Parque Nacional de Magóe poderá ser também tomado pelo setor privado como acontece com outras áreas de conservação distribuídos pelo país. Este processo tem culminado com a apropriação e privatização dos espaços naturais, pois depois que as empresas receberem concessões, criam suas próprias leis de acesso a estes lugares turísticos. A partir de então, a eclusão das populações locais passa a ser recorrente, pois para a sua entrada, é colocada uma taxa paga em forma de renda ao capitalista que detém o controle desta área.

A forma como o espaço turístico moçambicano vem sendo construído/produzido e organizado, além de evidenciar uma "seletividade espacial" ("elitização dos lugares turísticos"), é marcado também por conflitos sociais caracterizados por disputas territoriais. De um lado, estão as empresas que operam no ramo da conservação/preservação da biodiversidade querendo ampliar e/ou anexar outras áreas e, do outro, os camponeses e as comunidades rurais, lutando e resistindo para permanecer em suas terras. Mulhaísse (2018) em sua tese de doutorado, revela a emergência dos conflitos sociais resultantes da produção do espaço turístico no Parque Nacional de Gorongosa, localizado na província de Sofala. Este autor faz saber, por exemplo, que a ampliação da área do parque, levou a expopriação dos camponeses.

Este processo é relatado também por Catsossa (2019), mas a partir do Parque Nacional de Magoè, na província de Tete. Com a ampliação e anexação de outras áreas, os camponeses foram inibidos de realizar determinadas atividades, como, por exemplo, a casa, a pastagem de gado, corte de estacas, lenha, fabricação de carvão vegetal, etc. Este autor faz saber que, como estratégia de sobrevivência, algumas pessoas dentro das comunidades, tem facilitado determinadas empresas no corte de madeira dentro da área do Parque Nacional de Magoé.

Por sua vez, este processo é relatado também por Bruna (2020) e faz destaque do Parque Nacional do Limpopo, um parque transfroteiriço em que a gestão é compartilhada entre a República de Moçambique e a 
República da África do Sul. Esta autora, aponta, por exemplo, que o processo de implantação do parque levou a transferência e, consequentemente, o reassentamento de centenas de famílias camponesas que viviam dentro da área do parque e os que viviam na zona de Tampão. Para esta autora, o processo de reassentamento foi conflituoso, uma vez que não decorreu dentro das normas previstas na lei e como consequência disto, assiste-se a deterioração das condições de vida das famílias camponesas reassentadas.

Em relação a "seletividade espacial", ela inibe o acesso livre as pessoas de baixa renda aos lugares turísticos, passando assim, a serem frequentados por uma classe social que detém poder, neste caso, financeiro tal qual podemos observar nos sul-africanos, chineses, portugueses e dentre outras nacionalidades. Trata-se, portanto, de um processo contraditório e desigual de produção do espaço turístico, na medida em que o mesmo é oriantado para o mercado global, cujo objetivo é gerar lucro. Signifca que os nativos são excluídos em detrimento dos turistas estrangeiros.

Produzir um espaço turístico, significa acima de tudo, apropriá-lo para um determinado. Entretanto, enquanto "prática social modena", o turismo "depende da valorização do espaço e da organização estratégica dos territórios" (COSTA, 2010, p. 19 itálicos do orginal). A valorização do espaço para fins turísticos, significa acima de tudo, a sua transformação. Aqui, estamos diante da produção de uma nova paisagem, neste caso, artificial.

O fim como se verá mais em diante, é criar elementos que vão alienar quem pretende e/ou tem interesse em visitar os referidos espaços. Este processo leva a apropriação e privatização da natureza, na medida em que a mesma, é transformada de valor de uso para valor de troca. Ao ser transformada em um valor de troca, a partir deste momento, a natureza passa a configurar-se como um meio de acumulação ampliada do capital em escala global para quem a apropria e a privatiza. A esse respeito, Moretti (2012) afirma:

A transformação do valor de uso para valor de troca nas relações da sociedade com a natureza faz parte do processo de produzir a natureza para atingir o objetivo definido pelo modo de produção, ou seja, a reprodução ampliada do capital em escala ampliada (MORETTI, 2012, p. 17).

É o chamado "green grabbing" que é nada mais, nada menos que o processo de apropriação e privatização dos espaços naturais por meio de discursos conservacionistas e/ou preservacionistas. A preocupação ambiental em relação ao paradigma conservacionista e/ou preservacionista, trouxe outro elemento importante a temática sobre o meio ambiente. Para Gonçalves (2019) durante o debate em torno da questão ambiental ocorreu "a agregação do interesse econômico frente as políticas de conservação ambiental" no mundo. 
Convém realçar que, por de trás do discurso conservacionista e/ou preservacionista, está a ideologia do "desenvolvimento sustentável" ("sustentable development") e a ideologia da "economia verde" ("green economy") e adiciona-se também a ideologia da "economia azul" ("blue economy"). Tanto a ideologia do "desenvolvimento sustentável" quanto a ideologia da "economia verde" como a ideologia da "economia azul" são recriações do capital, e o discurso conservacionista/preservacionista presente nelas escondem o sentido primitivo do processo de produzir a natureza sob viés do modo capitalista de produção.

Dito de outro modo, tanto a ideologia do "desenvolvimento sustentável" quanto a ideologia da "economia verde" como a ideologia da "economia azul" fazem parte do processo de acumulação primitiva do capital, mas com elementos novos, típicos da atual era de globalização neoliberal.

Ao serem apropriados e privatizados, os espaços naturais são transformados no que podemos chamar "territórios da conservação", dentre eles, os parques e reservas nacionais, no caso de Moçambique. Esses territórios da conservação estão inseridos no chamado paradigma da "crise socioambiental". Nota-se, portanto, o que Santos (2013) chama de "compartimentação e fragmentação do espaço geográfico" o que para Fernandes (2008) seria o surgimento dos "territórios do território", os quais passam a ser governados e/ou geridos pelos "dinheiros globalizados" (Santos, 2011), mas, mascarado pelo discurso conservacionista e/ou preservacionista.

Em Moçambique, por exemplo, os investidores têm se beneficiado de concessões de médio e longo prazo, onde implantam instâncias turísticas. Neste contexto, os investidores operam "no modelo de concessões de 8.000 a 10.000 hectares para a implementação de instâncias turísticas de 3, 4 ou 5 estrelas e também para a operacionalização de safaris, pesca recreativa e outras actividades turísticas" (BRUNA, 2020, p. 3). Pode-se dizer que em Moçambique, está em curso uma nova onda de usurpação dos recursos naturais, mas desta vez, em nome da conservação e/ou preservação ambiental.

Em nome do ambiente, muitas empresas estão gerando lucros extraordinários a partir da natureza, sobretudo, após transformá-la em um atrativo turístico a ser comercializada para o mercado global do turismo. O que está acontecendo em Moçambique neste caso concreto, é o que Harvey (2005) chama de "produção capitalista do espaço", pois trata-se de um processo de "expansividade do capitalismo" (COSTA, 2010) contemporâneo, que aos poucos, vai moldando e criando condições (i)materiais com vista a garantir acumulação ampliada do capital em sua escala global. Em Moçambique está em curso um fenômeno igual ao que Silveira (1997) chamou de "fetichização dos lugares", na medida em que este processo é acompanhado pela produção de imaginários que aos poucos, vão alienando as mentes das pessoas para visitar estes lugares.

Para Silveira (1997) estaríamos diante da "psicosfera", que quando apropriada pela ideologia capitalista, produz elementos alienantes, os quais funcionam como atrativos turísticos passíveis de serem 
consumidos pelos turistas. Neste processo, cria-se uma imagem da existência da "aptidão paisagística dos lugares turísticos" enquanto "um conjunto de dados psiconaturais e técnicos de um lugar que constituem o domínio visível, isto é, a paisagem" (SILVEIRA, 1997, p. 37).

Enquanto atividade econômica, em Moçambique o turismo é praticado por pessoas majoritariamente estrangeiras, sobretudo, sul-africanos. Em termos de organização e estrutura do turismo, pode-se dizer que este setor da economia ainda encontra-se em fase de crescimento.

As estatísticas nacionais dos indicadores do setor do turismo, neste caso, a oferta de produtos e os serviços prestados, mostram um crescimento em determinadas províncias em relação a outras (cf. INE, 2014, 2018). Comparativamente a outros países africanos, Moçambique conta com características e elementos muito particulares, capaz de fascinar aqueles que se dispõem a viver uma experiência em suas terras. Em termos de recursos naturais, podemos dizer que é um país rico, entre eles, recursos minerais e energéticos, florestas e faunísticos e hídricos em grande proporções. Por sua vez, Moçambique tem uma paisagem deslumbrante, composta por praias, parques nacionais, reservas, que são, portanto, atrativos turísticos do país. Estimativas atuais, dão conta que, Moçambique:

\footnotetext{
[...] abarca mais de 5.500 plantas, 220 mamíferos e 690 espécies de aves, muitas das quais endémicas. As principais atrações estão ao longo da linha costeira de Moçambique com $2.700 \mathrm{Km}$ com praias de palmeiras, lagoas e ilhas, incluindo os arquipélagos de Bazaruto e das Quirimbas, extensos recifes de coral, parques nacionais e reservas que estão sendo repovoados com uma variedade de fauna bravia. De uma área total de $780.000 \mathrm{~km}^{2}, 87.000 \mathrm{~km}^{2}$ de áreas protegidas $(11,1 \%)$, o País é povoado, com grandes áreas de terra não exploradas. A mistura de influências Africana, Árabe e Portuguesa do País é evidente na vibrante vida noturna e na gastronomia (MOÇAMBIQUE, 2015, p. 5).
}

Estes aspectos fazem com que Moçambique seja um dos principais pontos turísticos, não apenas da África, mas também do mundo. Além das lindas praias que se encontram em quase todas a zona costeira, o país tem uma paisagem deslumbrante e fascinante, que é propícia para a prática do turismo de natureza ou ecoturismo. Neste caso, a paisagem seria o atrativo turístico. Essa paisagem natural deslumbrante e fascinante foi observada na província de Manica, sobretudo, na cidade de Chimoio. A “Cabeça de Velho" localizada na cidade de Chimoio, é um dos atrativos turísticos, mas não é muito aproveitado para esta atividade econômica.

Figura 1: “Cabeça de Velho", cidade de Chimoio/Moçambique Fonte: CATSOSSA, L. A (2020). 


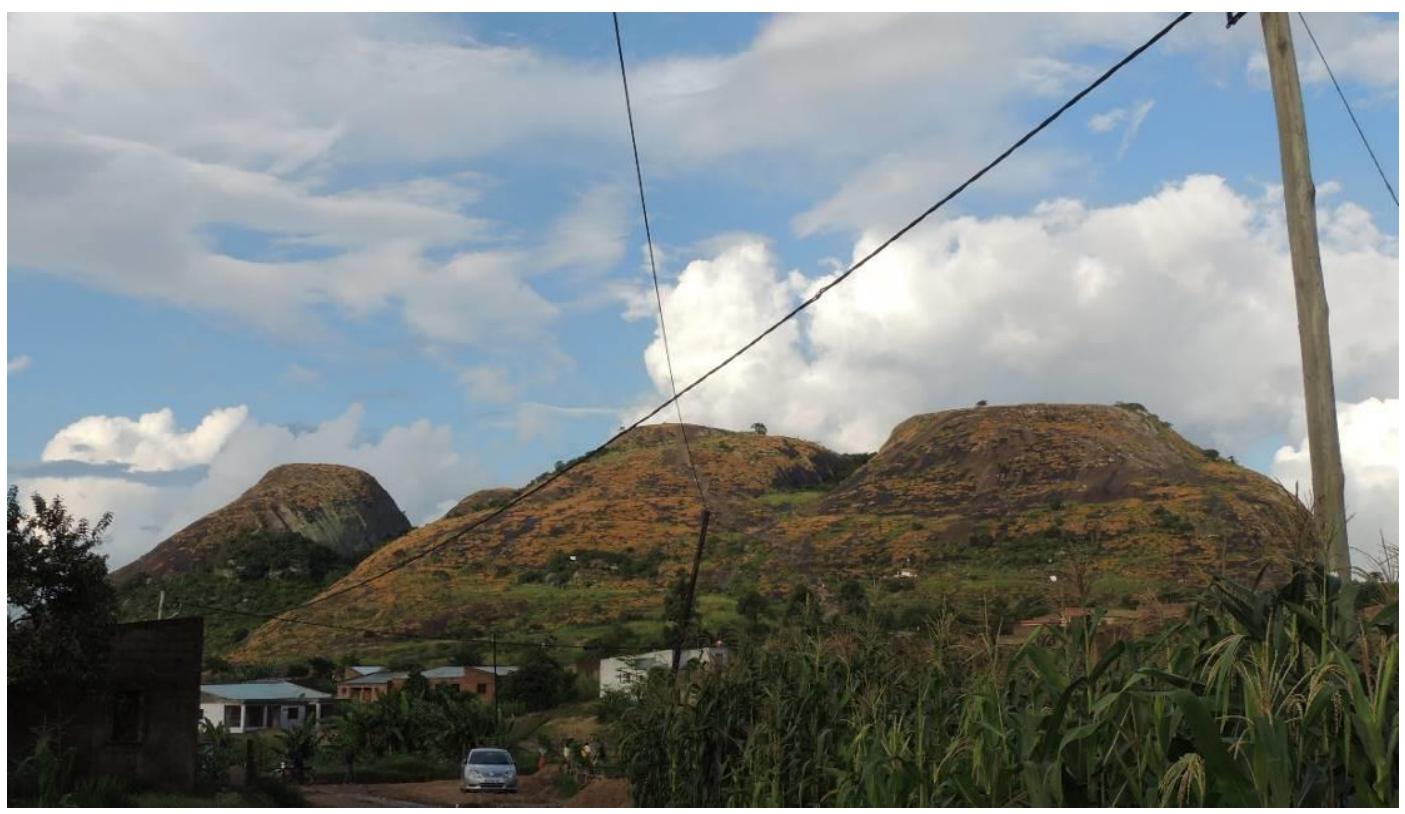

"Cabeça de Velho", na cidade de Chimoio, província de Manica, é apenas um exemplo da beleza, que o país apresenta enquanto, atrativo turístico. Este lugar é mais frequentado pelas populações nativas que estrangeiros. Por exemplo, nas proximidades da "Cabeça de Velho", estão sendo erguidas algumas infraestruturas para receber turistas. Para dizer que, enquanto espaço turístico, "Cabeça de Velho" ainda está em produção.

Nos últimos anos, o Estado tem promovido ações para a prática do turismo de natureza. Por causa da bela paisagem, o governo tem organizado eventos internacionais com vista a promoção de "Turismo de Natureza". O objetivo destes eventos internacionais tem sido apresentar as potencialidades que o país apresenta para a prática do turismo de natureza. Em 2017, o governo organizou a primeira Conferência Internacional sob lema Turismo baseado na Natureza.

Figura 2: Conferência Internacional "Turismo baseado na natureza”, Maputo/Moçambique Fonte:https://www.google.com.br/search?q=turismo+de+natureza+em+mo\%C3\%A7ambique\&sxsrf=ALeKk03Lr4jx1M7Sroq297f8pd 


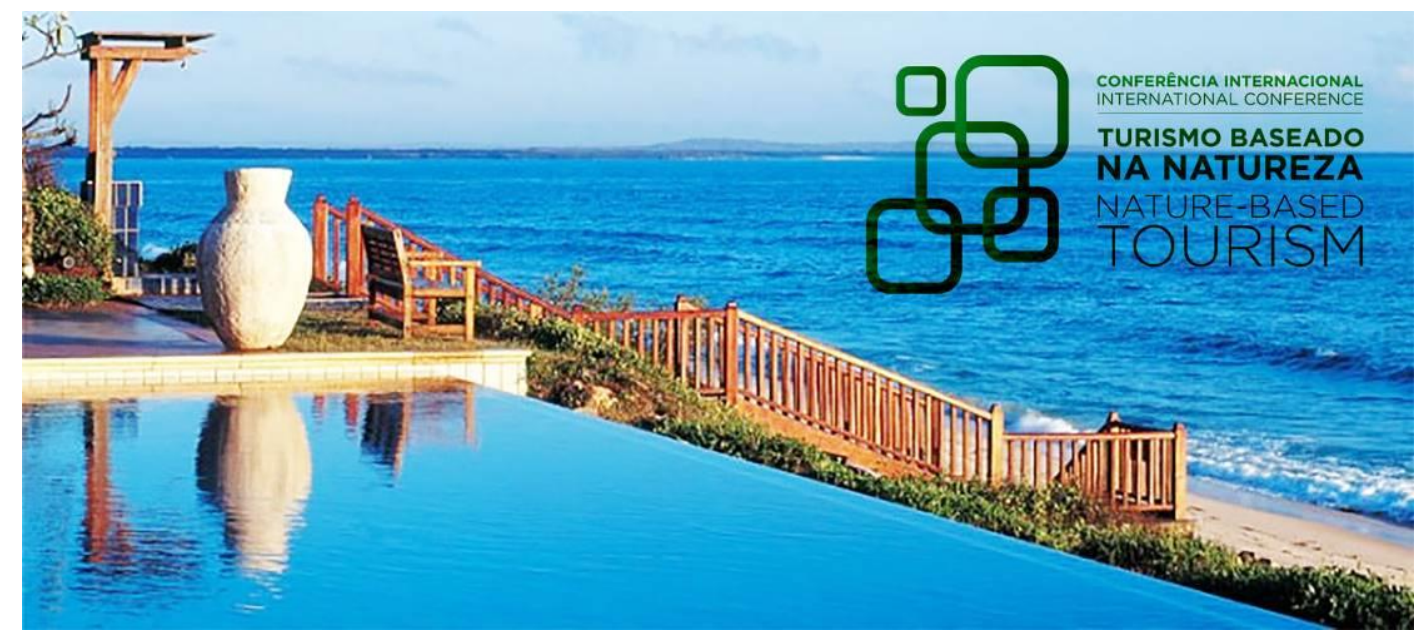

Além do setor privado nacional e estrangeiro, nessa conferência participaram várias entidades nacionais e estrangeiras, dentre elas, chefes e ex-chefes de Estado, instituições multilaterais -, com destaque para o Banco Mundial. Além de ter se configurado em um espaço para a troca de experiências, para alguns participantes, sobretudo, o setor privado nacional e estrangeiro, esta conferência foi uma oportunidade para negócios. Além disso, ela contou com diversas personalidades tais como: políticos, empresários, acadêmicos e especialistas de 25 países visando debater a importância da conservação da biodiversidade enquanto um atrativo turístico no mundo. Fazendo referência a esta conferência, o governo por via do extinto Ministério da Terra, Ambiente e Desenvolvimento Rural (MITADER -, atualmente, Ministério da Terra e Ambiente) responsável pelas áreas de conservação no país, afirmou o seguinte:

\begin{abstract}
A nível global, os governos nacionais, ONGs e os gestores de áreas de conservação enfrentam desafios para conseguir financiar a proteção dos habitats e espécies e, ao mesmo tempo, garantir que as comunidades locais se beneficiem das áreas de conservação. O turismo baseado na natureza, surge como uma das soluções para resolver o dilema. Ao promover a fauna bravia e os espaços naturais como atrações, os países podem preservar os ecossistemas e gerar empregos para as populações que vivem mais próximo de animais selvagens. Esta conferência internacional pretende explorar mecanismos de desenvolvimento do turismo baseado na natureza nas áreas de conservação, de forma a fornecer resultados para as pessoas e a vida selvagem. O turismo é uma indústria prioritária para o Governo de Moçambique e o Estado está empenhado em criar oportunidades que explorem e enalteçam o poder do desenvolvimento. Para este efeito, o Governo estabeleceu as condições necessárias para que as áreas de conservação implementem as parcerias público-privada. As parcerias público-privadas são indispensáveis para oferecer um turismo de primeira classe nas áreas de conservação e também garantir que essas áreas selvagens sejam protegidas para o futuro. A co-gestão das áreas de conservação é uma forma inovadora de aceder aos recursos técnicos, profissionais e financeiros necessários ${ }^{1}$.
\end{abstract}

\footnotetext{
${ }^{1}$ Disponível em: https://www.mitader.gov.mz/conferencia-internacional-do-turismo-baseado-na-natureza/. Acesso em 23 de fev. de 2020.
} 
Mas, vale realçar que, não é apenas o turismo de natureza que o governo tem procurado promover em Moçambique. Pelo contrário, verifica-se também a promoção do turismo cultural. Nos últimos anos, turismo e a cultura tem andado de "mãos dadas", enquanto atrativos turísticos. Aliás, o próprio ministério se chama "Ministério da Cultura e Turismo", uma clara confirmação de que o turismo e a cultura andam de "mãos dadas" em Moçambique. Por exemplo, antes da fusão, os Ministério da Cultura e Turismo funcionavam de forma autonôma.

Mais tarde, compreende-se que havia uma necessidade de juntar cultura e o turismo no mesmo ministério e esta, foi uma ideia bem pensada. Para tal, o governo tem organizado eventos internacionais para a promoção da natureza e a cultura no país. Em consonância com isso, ele organizou em 2019, entre os dias 31 de Outubro a 03 de Novembro, a «FIKANI - Feira Internacional de Turismo de Moçambique» e subordinouse ao tema "Turismo e Cultura: promovendo o emprego e o bem-estar" e ocorreu na cidade de Maputo [vide figura 3].

Figura 3: Feira Intenacional de Turismo de Moçambique/Maputo Fonte:

http://www.micultur.gov.mz/index.php/turismo/556-vii-edicao-da-feira-internacional-de-turismo-abre-hoje-em-maputo. Acesso em: 22 de fev. de 2020.

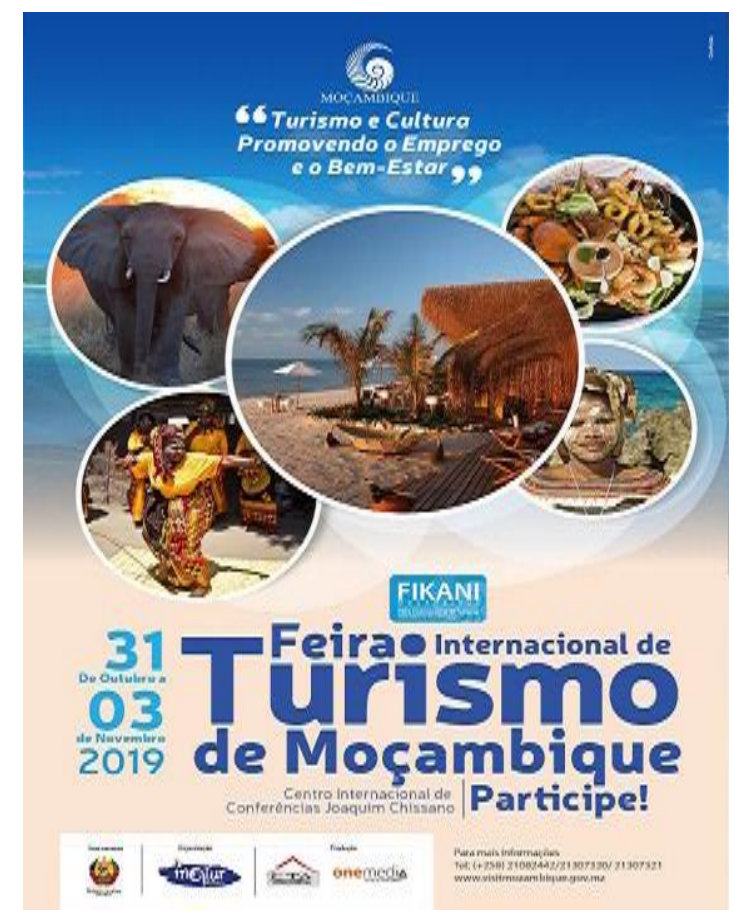

Em uma tentaiva de fazer da cultura um atrativo turístico em Moçambique, o governo tem organizado festivais culturais que acontecem de forma rotativa em todas as províncias do país. Por exemplo, cada província envia seus representantes, os quais apresentam o que têm de melhor em termos culturais a ser explorado pelo turismo. A figura 4, mostra a publicidade da IX Festival Nacional da Cultura, ocorrido entre os dias 24 a 29 de Agosto de 2016, na província central de Sofala. 
Figura 4: IX Festival Nacional da Cultura, Sofala/Moçambique Fonte: http://www.micultur.gov.mz/index.php/ix-festivalnacional-da-cultura/348-beira-acolhe-a-cerimonia-central-de-lancamento-do-ix-festival. Acesso em: 24 de fev. de 2020.

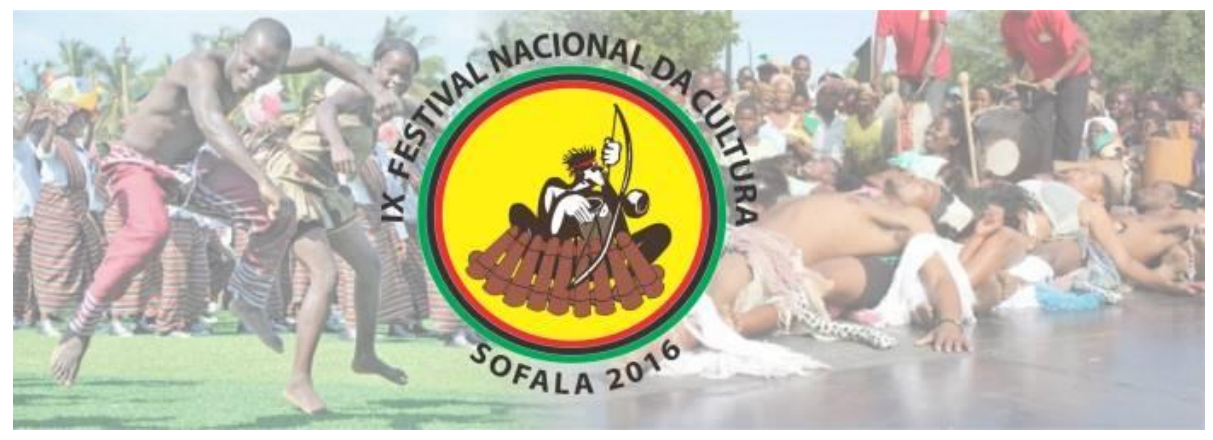

Nos festivais nacionais da cultura, além da dança, cada província apresenta cânticos, pratos típicos (comida), artesanato e entre outros atrativos turísticos. Em muitos países do mundo, o turismo tem sido um dos setores pelos quais as divisas entram nos cofres do Estado. Há países, por exemplo, que tem o turismo como um dos principais setores dinamizadores da sua economia. Estes países, criaram uma estrutura própria para que o turismo se fizesse de fato, um dos setores que mais contribui para os cofres do Estado. Cuba é um dos países que tem o turismo como setor importante da sua economia, por isso, a sua estrutura e organização é bem consolidada.

Diferentemente de Cuba, embora seja um dos países que Moçambique diz inspirar-se, o setor do turismo ainda não está organizado de tal forma que, consiga dinamizar a economia nacional. Moçambique tem tudo para o turismo ser um sucesso, mas a riqueza natural e cultural que o país apresenta não é aproveitada. Olhando para os atrativos turísticos que possui, era suposto que o país tivesse arrecadado muita divisa, mas é o turismo um dos setores que pouco contribui para a economia do país. Para tal, governo moçambicano tem criado plataformas para que o turismo traga benefícios econômicos para o país.

Os festivais culturais, além de serem usado para momentos de convivências entre os povos de todo o país, tem sido uma das estratégias que o governo tem usado para a promoção do turismo, sobretudo, o turismo cultural. Ao juntar o setor do turismo e da cultura, para o mesmo ministério, foi estratégico, pois a ideia era, portanto, fazer face a dinamização do turismo em Moçambique. Entretanto, o governo moçambicano tem investido na diversificação do setor do turismo como uma forma de atrair mais turistas e por via disto, captar divisas para o país. Por exemplo, o Plano Estratégico para Desenvolvimento do Setor do Turismo (2016-2025), descreve o seguinte:

Usar o turismo como um mecanismo para a diversificação e crescimento da economia proporciona muitos benefícios, incluindo o aumento das receitas fiscais, criação de empregos, oportunidades para pequenas e médias empresas, desenvolvimento de competências, a sustentabilidade ambiental e o 
desenvolvimento econômico local, em especial, quando os bens e serviços são produzidos localmente. Dados os excepcionais recursos naturais e culturais de Moçambique não há dúvida de que o turismo é uma das opções mais realistas e viáveis para diversificar a economia durante a próxima década e para a mitigação dos potenciais desafios que emanam da expansão atual de recursos (MOÇAMBIQUE, 2015, p. 5).

Nos últimos anos, o setor do turismo tem sofrido várias transformações e uma das aposta do governo tem sido as obras de infraestrutura, elas estão inseridas na ideia da produção do espaço turístico na cidade de Maputo. Dentre estas, podemos enlencar a ponte Maputo-Catembe:

[...] foi construída pela China Road and Bridge Corporation, tendo os trabalhos começado em Setembro de 2012 e o valor do investimento ascendido a 725 milhões de dólares (621 M€). O projeto inclui a ligação rodoviária entre a Catembe e a Ponta do Ouro, no extremo sul de Moçambique, uma área de praia que faz fronteira com a África do Sul. A ponte, sobre a baía do Maputo, tem uma extensão de cerca de três quilômetros, com quatro faixas para a circulação de viaturas, duas em cada sentido².

Além de pretender fazer a ligação entre a cidade de Maputo e Catembe, através desta obra pretendese criar condições para que os turistas tenham acesso a Ponta de Ouro. A ideia é garantir a circulação de pessoas, não apenas daquelas que vão a Catembe enquanto espaço habitacional e de trabalho, muito pelo contrário, mas também as que vão a Ponta de Ouro para usufruir da beleza natural que espaços turísticos apresenta.

Figura 5: Obras de construção da ponte Maputo-Catembe/Moçambique Fonte: CATSOSSA, L. A (2017).

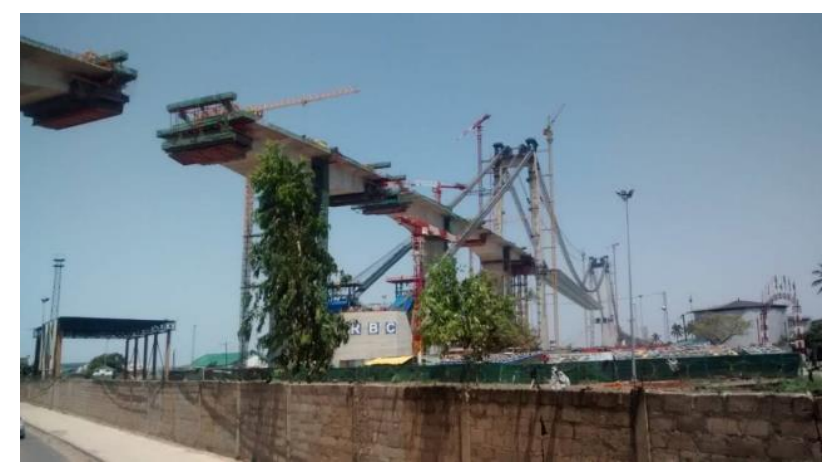

Desde que essa obra foi inagurada ela dinamizou a circulação de pessoas e bens em Catembe como também a atividade turística na Ponta de Ouro. Por exemplo, antes da ponte a travessia para Catembe e Ponta de Ouro era feita por pequenas embarcações (batalões). Vários acidentes, como, por exemplo, naufrágios, já ocorreram na travessia em pequenas embarcações para Catembe. Para dizer que, a ponte Maputo-Catembe, por um lado, foi erguida para diminuir o sofrimento das pessoas, evitando mais naufrágios, sobretudo, mortes

2 Disponível em: https://www.ilhademocambique.co.mz/content/inauguracao-da-maior-ponte-suspensa-da-africa. Acesso: 20/02/2020. 
e, do outro, para dinamizar o setor turístico neste ponto do país. Vale ressaltar que, a construção da ponte levou a deslocamento de centenas de familias que viviam por onde ela passou.

Após serem deslocadas, estas famílias foram reassentadas em outros lugares, mais distantes. Tendo em conta que nos locais de reassentamento não havia condições básicas (escolas, postos de saúde, mercados, fontes de abastecimento de água, transporte, etc.), verificou-se a eclosão de conflitos sociais. Parte destas famílias reassentadas, foram indenizadas, mas segundo as denúncias populares, o dinheiro não foi suficiente para se reerguerem. Além da ponte Maputo-Catembe, foi construída também a Estrada Circular de Maputo. Com cerca de 74 km de extensão, a Estrada Circular de Maputo liga as cidades de Maputo e Matola, respectivamente, atravessando o distrito de Marracuene e foi orçada em 315 milhões de dólares ${ }^{3}$. A Estrada Circular de Maputo, estrutura a cidade de Maputo e alivia o trafégo, sobretudo, o engarrafamento na horário de pico dos carros, que saem para alguns bairros periféricos de Matola e Marracuene.

Figura 6:. Estrada Circular de Maputo/Moçambique Fonte: https://realestate.co.mz/2019/03/19/ministro-pede-manutencaoimediata-da-estrada-circular-de-maputo/ . Acesso em: 20 de fev. de 2020.

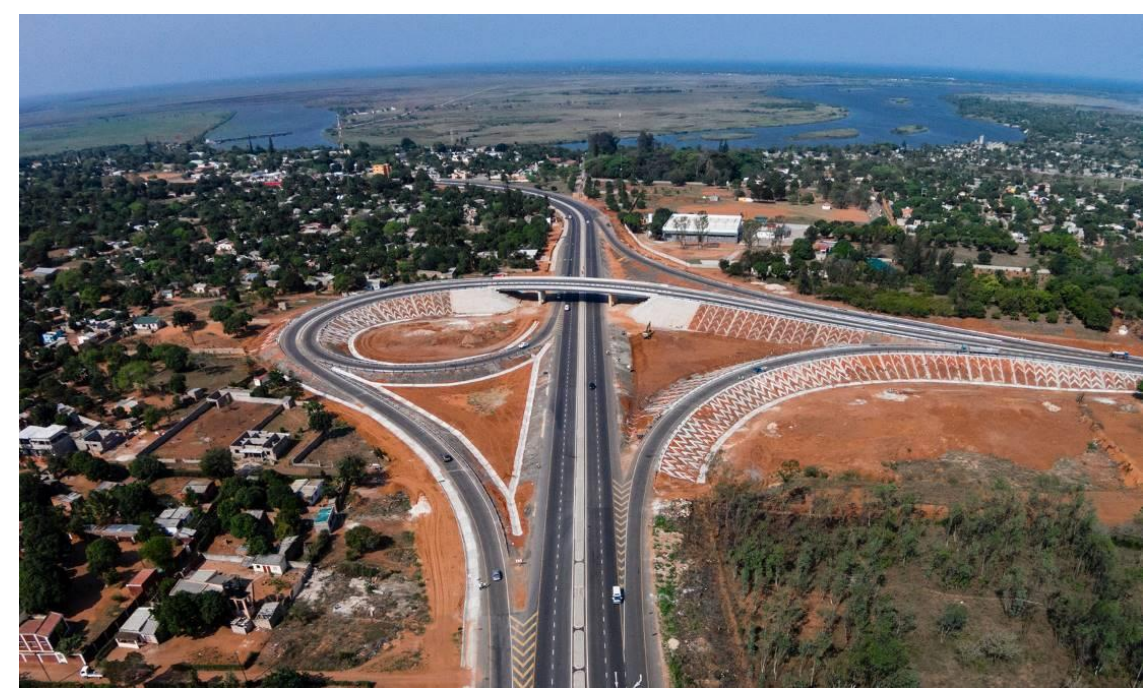

A Estrada Circular de Maputo permite a circulação de turistas para diferentes pontos da cidade de Maputo como, por exemplo, a praia da Costa do Sol, sítios culturais dentre outros. Além disso, permite a circulação de turistas para a praia de Macaneta, no distrito de Marracuene. Durante a pesquisa de campo, foram realizadas algumas visitas à praia de Macaneta observamos algumas transformações desde o acesso

\footnotetext{
${ }^{3}$ Disponível em: http://www. plataformamacau.com/mocambique/estrada-circular-de-maputo-pronta-no-natal. Acesso em: 20 de fev.
} de 2020. 
até a chegada ao distrito como, por exemplo, partindo de Maputo a revitalização da orla da Costa do Sol e as construções chinesas que estão sendo feitas nesse local, conforme figura 7.

Figura 7: Revitalização Orla Costa do Sol, cidade de Maputo/Moçambique Fonte: Gonçalves, K. B (2016).

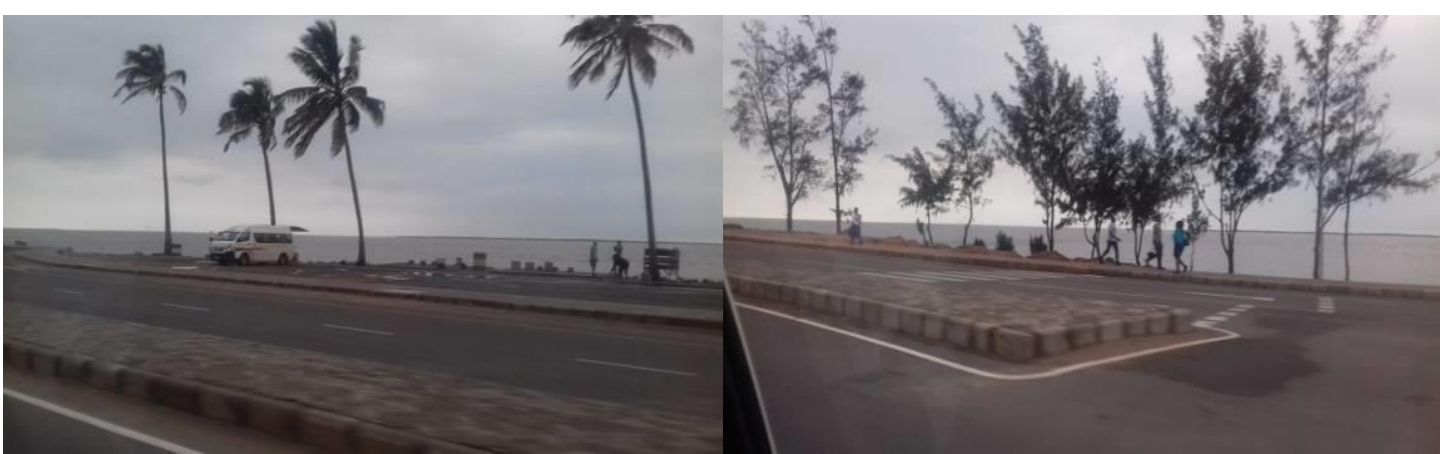

Ao longo da Marginal, por exemplo, foram erguidas diversas construções, principalmente hoteleiras, as quais recebem turistas de vários países do mundo, conforme se pode visualizar na figura 8.

Figura 8: Hotel Chinês (à esquerda) e Hotel Radisson (à direita) na Costa do Sol, cidade de Maputo/Moçambique Fonte: Gonçalves, K. B (2016).

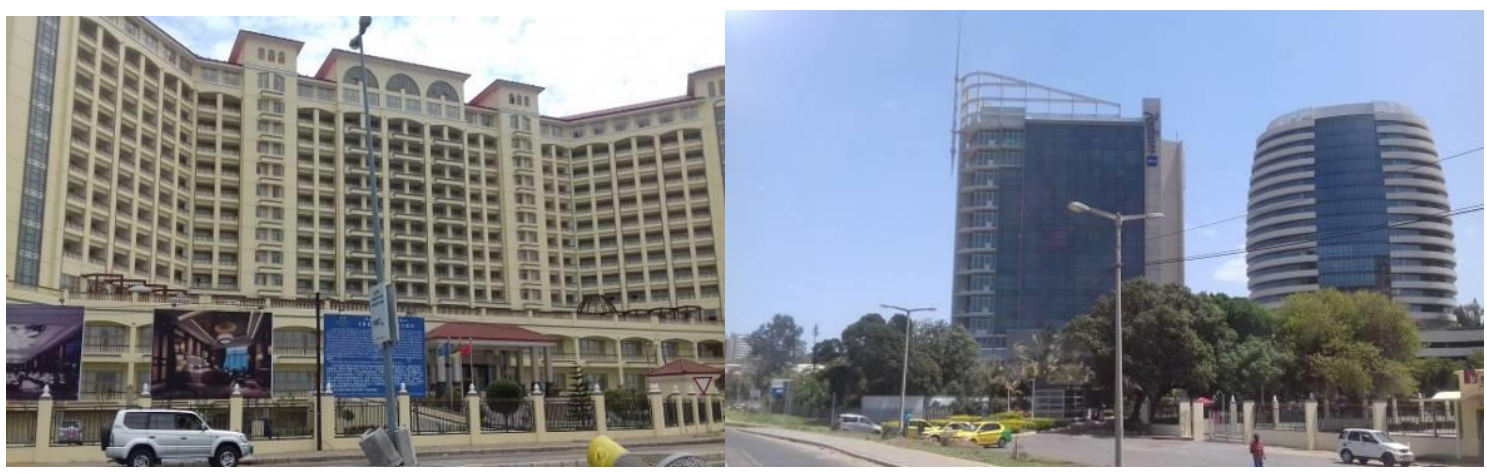

Ao andar pela orla Costa do Sol, constatamos que ocorreu uma aproximação entre as construções do espaço urbano, ou seja, os residenciais, hotéis, comércios e a praia. Foi possível observar, que essas construções e melhorias na infraestrutura do lugar até podem contribuir para deixar o espaço mais admirável e acessível à população, no entanto, em dias de vento a areia da praia acaba invadindo o asfalto, o que frequentemente gera maior trabalho para o pessoal que cuida dos serviços de limpeza urbana. 
Além disso, essas áreas há alguns anos atrás eram manguezais, e não eram áreas propícias a construção de infraestruturas. Podemos dizer que, há uma invasão de espaços que seriam, portanto, de proteção/conservação pela ação humana. Em Moçambique, está em curso o processo de apropriação e privatização dos "espaços natuais" (para não dizer da natureza) pelo capital e mais tarde, são transformados em "espaços turístico". Após a sua transformação, o ingresso a esses espaços é cobrado.

Logo, estamos, portanto, diante da transformação dos elementos naturais, enfim, da natureza em mercadoria, a base para acumulação ampliada da natureza. Nessa perspectiva, entendemos que os moçambicanos interagem com o seu território com algumas particularidades que se manifestam através de elementos culturais, econômicos e políticos. E essas características provêm de seus costumes, das trajetórias de vida, das vivências bem como aquelas transmitidas pelos seus antepassados.

Portanto, para poder relatar as experiências vivenciadas no distrito de Marracuene bem como analisar as dinâmicas territoriais advindas do processo de desenvolvimento das atividades turísticas, ressaltamos que a territorialidade será analisada como um laço que o sujeito constrói com o território, e isso acaba influenciando nas relações que são estabelecidas entre os mesmos e seu território.

\section{O Turismo e as dinâmicas territoriais em Marracuene}

No caso de Moçambique as relações que são estabelecidas nesse território são múltiplas, o país possui uma infinidade de referenciais culturais e características próprias que se tornam evidentes na relação com o outro. Trata-se de uma cultura muito receptiva que ainda mantém firme seus costumes, saberes e referências. Em relação ao crescimento e estruturação do turismo é possível identificar que nos últimos anos o país tem apresentado avanços e isso tem modificado a forma como o território tem sido organizado. Para falar do turismo em Marracuene é importante apontar algumas obras que foram feitas no acesso ao distrito partindo de Maputo.

Seguindo essa lógica das construções notamos que algumas obras como a construção da chamada "Circular" que é uma ponte que liga a cidade de Maputo ao distrito de Marracuene e a praia de Macaneta, contribuíram muito para o acesso tanto da população quanto dos turistas ao distrito e a praia. Há cerca de um ano e meio, ou no máximo dois anos, quando não havia a circular a travessia era feita por meio de balsas. Foi um grande investimento feito em sua maioria por capital chinês. A figura 9, permite observar a dimensão dessa obra: 
Figura 9: Construção da Ponte chamada Circular (à esquerda) e Margens da Circular (à direita) Autora: GONÇALVES, K. B.

(2016).

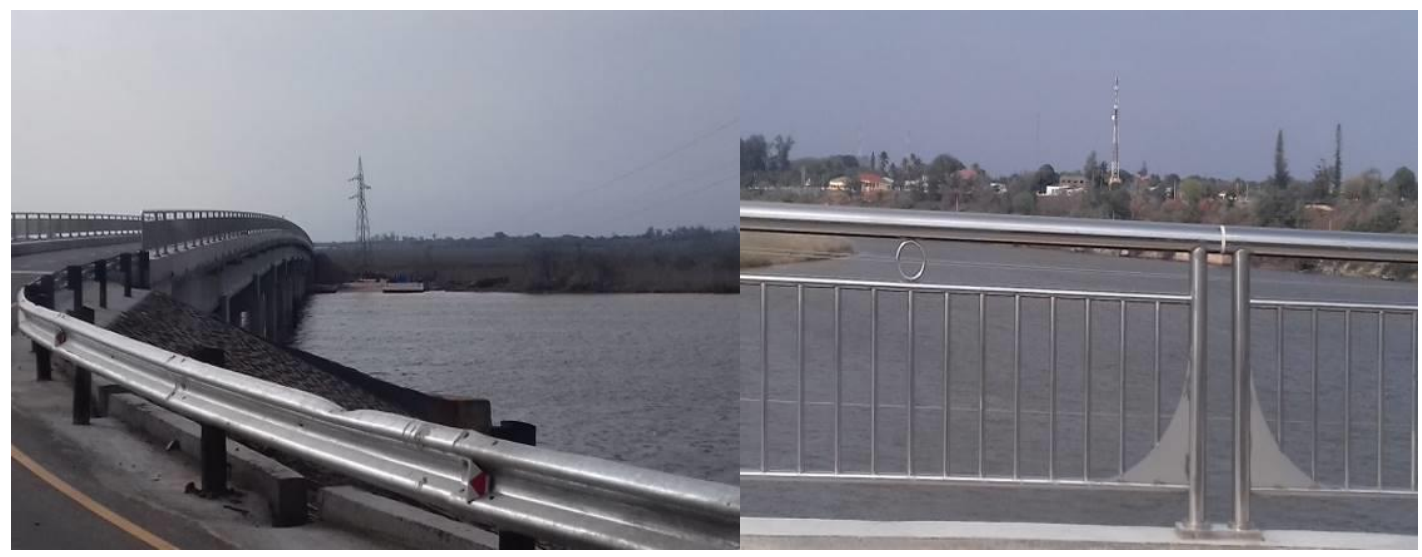

Ainda a caminho da praia de Macaneta, passando pelo perímetro urbano de Marracuene, é possível visitar a feira de pequenos agricultores, caracterizado pelo comércio informal, em sua maioria mulheres, que comercializam os produtos de suas machambas (pequenas parcelas de terras onde se desenvolve práticas agrícolas). É importante ressaltar que em Moçambique, diferente do Brasil, não existe a propriedade privada da terra, ou seja, obtém-se o direito de uso de uma parcela de terra:

\footnotetext{
Na República de Moçambique a terra é propriedade do Estado e não pode ser vendida, ou por qualquer outra forma, alienada, hipotecada ou penhorada. Como meio universal de criação da riqueza e do bemestar social, o uso e aproveitamento da terra é direito de todo povo moçambicano. As condições de uso e aproveitamento da terra são determinadas pelo Estado. O direito de uso e aproveitamento da terra é conferido às pessoas singulares ou coletivas tendo em conta o seu fim social (MOÇAMBIQUE, 2015, p. 01).
}

Mesmo sendo propriedade do Estado, o acesso à terra tem se tornado um problema para muitos camponeses. Dentro da sociedade moçambicana, há, portanto, um entendimento segundo o qual, em Moçambique está em curso um processo de privatização e mercantilização da terra, isto num contexto de propriedade da terra. De fato, os títulos de terras têm sido comercializados a preços exorbitantes e isto ocorre com frequência nas cidades. Verifica-se, portanto, uma especulação e para obterem maiores lucros, os seus detentores dividem em pequenas parcelas e depois, vendem aos que precisam da terra. O mercado de terras em Moçambique é mais ativo nas cidades sendo, contudo, elevado em áreas turísticas.

O mercado de terras em Moçambique vem crescendo também no campo e deve-se a recente expansão do agronegócio (cf. CATSOSSA, 2020). Por causa desta privatização estatizada da terra que se verifica em Moçambique, muitos camponeses (homens e mulheres) que desenvolvem atividades agrícolas, ocupam espaços reduzidos. E depois de produzirem comercializam seus produtos em pequenas feiras ou em alguns espaços da cidade, muitas vezes nas esquinas das ruas. Em relação à infraestrutura do local que abriga a feira 
de Marracuene que ocorre aos sábados, podemos observar que ainda é precário, pois a maioria das mulheres comercializam seus produtos no chão, conforme podemos visualizar nas fotos a seguir.

Figura 10: Feira de Marracuene (à esquerda) e maneira de comercializar os produtos (à direita)

Autora: GONÇALVES, K. B. (2016).

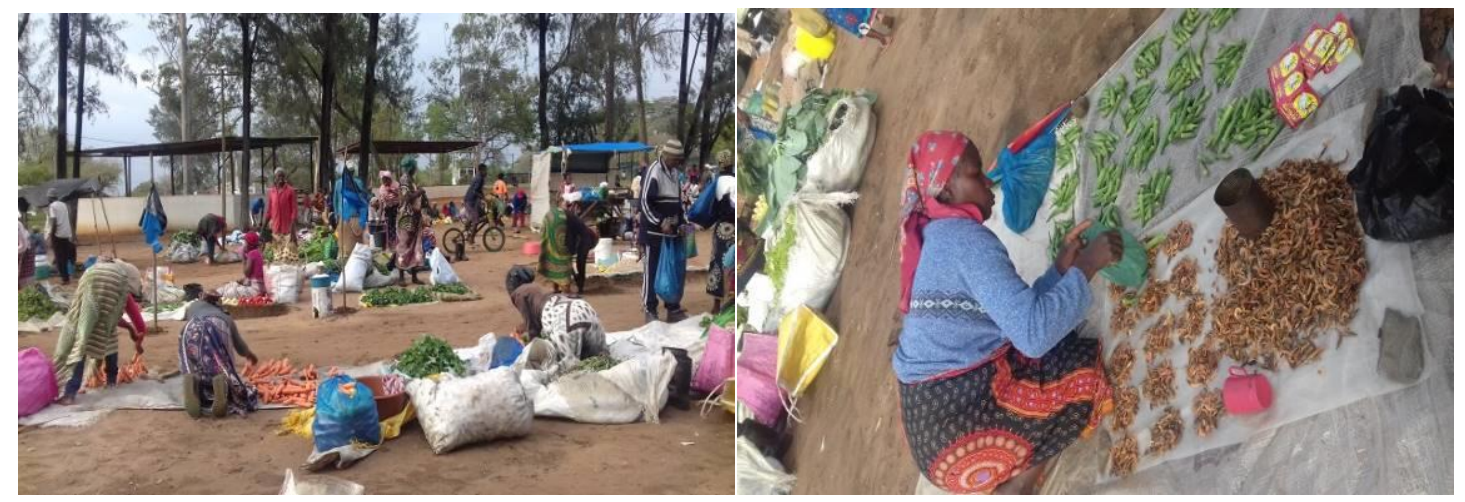

Logo após visita a feira de mulheres, seguimos para a praia de Macaneta, que é uma praia do oceano Índico. Ao chegarmos no local de acesso à praia, notamos que uma parte considerável dos lotes estavam demarcados e cercados, e que o acesso à praia por meio de veículos motorizados estava limitado, pois para ingressar nos caminhos de acesso era cobrado uma taxa, justificada pelo fato de serem veículos motorizados. Chegando a praia de Macaneta, o nosso intuito era identificar como as atividades turísticas tem crescido na região, além de observar as práticas dos pescadores locais. Quando nos aproximamos do local grande parte dos pescadores já estavam no mar com suas redes lançadas, ficamos na praia até o retorno dos mesmos, e presenciamos a chegada dos outros integrantes de suas famílias que auxiliam na puxada da rede de pesca.

Figura 11: Pescadores da praia de Macaneta (à esquerda) rede utilizada para a pesca (à direita) Autora: GONÇALVES, K. B.

(2016).

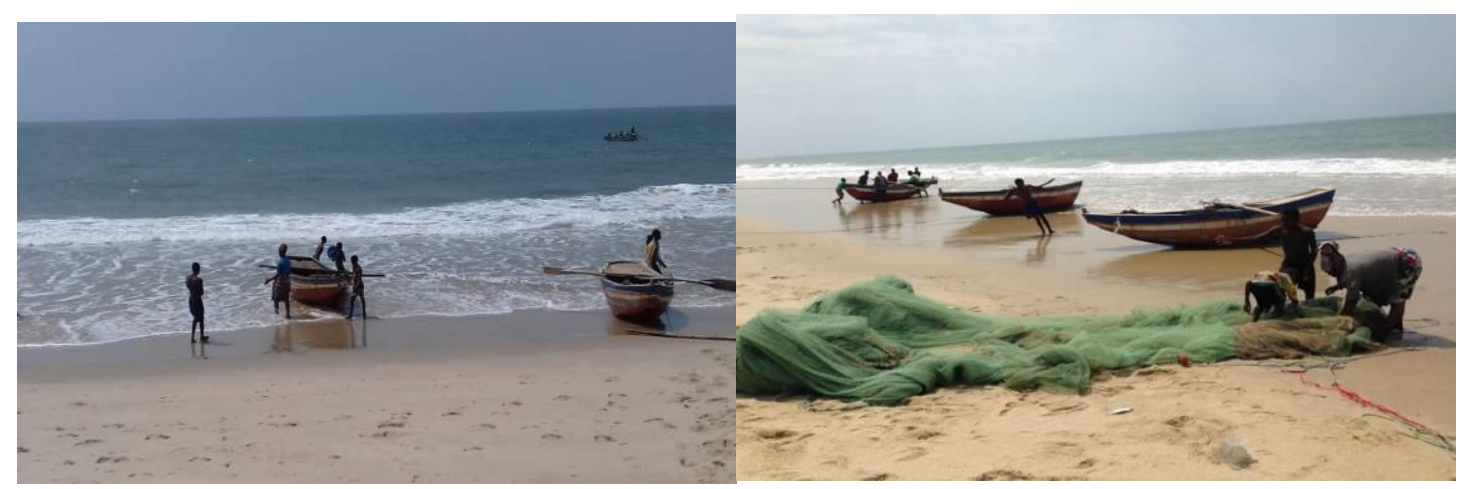


Depois que os pescadores terminaram de puxar suas redes, conversamos com alguns no intuito de saber como estavam às atividades de pesca da região, e grande parte nos relatou que nos últimos dias havia diminuído a quantidade de peixes, mas que havia épocas em que a pesca era farta. Os peixes são vendidos por quilo para o comércio local, para os turistas que vem na praia, e quando eles têm pescas abundantes, as mulheres acabam comercializando no distrito de Marracuene na feira.

Após observar as atividades dos pescadores recorremos à praia de Macaneta para observar de que maneira está ocorrendo o crescimento do número de estabelecimentos comerciais nessa área. Foi possível perceber que houve um grande crescimento no número de hotéis e pousadas na região, e grande parte dos donos são estrangeiros, em sua maioria de nacionalidade sul-africana. Na figura 12 é possível visualizar alguns dos estabelecimentos que estão instalados em áreas próximas a praia.

Figura 12: Comércios Praia de Macaneta (à esquerda) e Quiósques comerciais (à direita) Autora: GONÇALVES, K. B. (2016).

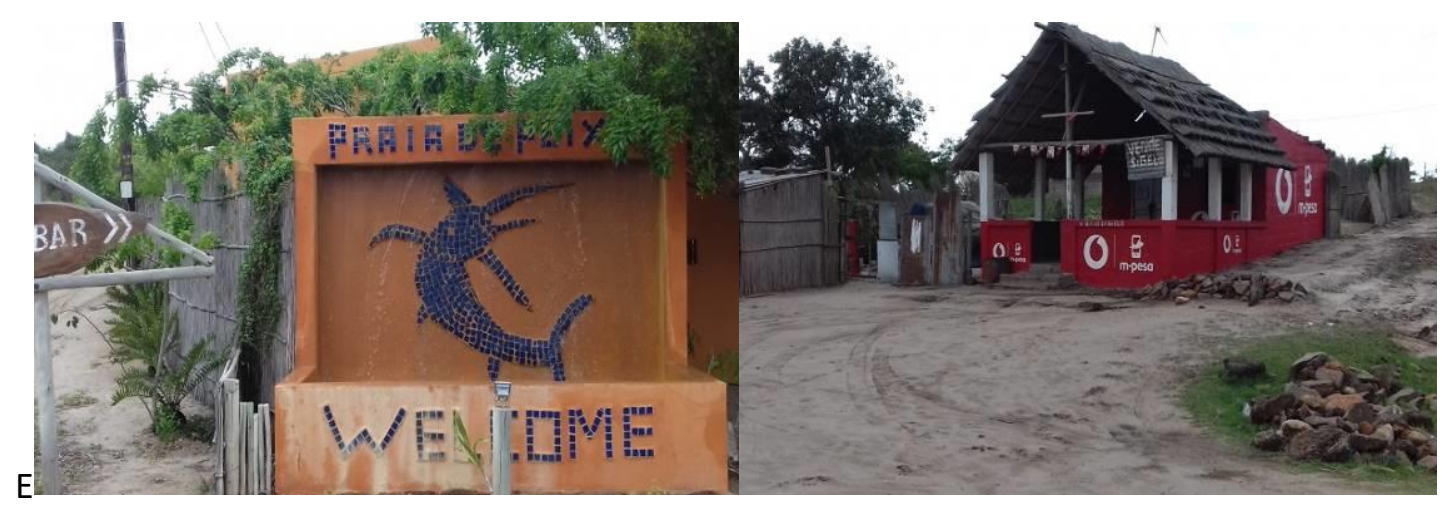

Em relação ao turismo no distrito de Marracuene evidenciamos que o mesmo tem como principal alvo a Praia de Macaneta, ou seja, o "turismo de praia e sol", que em sua maioria é voltado para os turistas estrangeiros. No relato a seguir é possível observar como se encontra estruturado o turismo na região da Praia de Macaneta:

\footnotetext{
O nosso turismo é um turismo de praia e sol, em nível de distrito temos 147 estabelecimentos comerciais, em que se destaca as estâncias turísticas, hotéis, lojas e pousadas. Na praia de Macaneta temos registrado 37 estabelecimentos comerciais. Temos diversas atividades como, por exemplo, a prática do hipismo onde temos 14 cavalos a disposição dos turistas, além de atividades de canoagem e caiaque. Nas estâncias turísticas temos algumas na forma matriarcal, feito de caniço e palha, como também temos construção de quartos definitivos. A maior parte dos empresários que estão instalados aqui são estrangeiros, e muitos da África do Sul. O nosso turismo vive uma fase embrionária eu penso que com a ponte que foi construída vai revolucionar a praia de Macaneta. Em termos de comodidade até o momento o máximo que temos é um hotel quatro estrelas. Estamos em crescimento com a reestruturação de alguns aspectos. Por exemplo, nós não tivemos o cuidado de deixar espaços públicos para as pessoas locais terem acesso à praia, então hoje os acesso estão cheios de cancelas, não existem caminhos abertos. Já temos definido abrir caminhos públicos para que todos tenham acesso à praia, ou
} 
seja, um caminho com a largura de três metros para não haver transtornos. A limpeza da praia é de responsabilidade de cada estância turística, mas também vão esporadicamente pessoas do governo fazerem a limpeza. A capitânia da polícia está presente na praia (Entrevistada I, Serviço Distrital de Atividades Econômicas de Marracuene, 17/10/2016).

Logo, nota-se que o turismo que vem sendo desenvolvido em Marracuene tem como propulsor a Praia de Macaneta, que embora esteja em fase embrionária possui uma característica peculiar, ou seja, as atividades desenvolvidas ali estão voltadas para um público global, e não local. Tanto que os caminhos que dão acesso à praia começaram a serem controlados por meio de cancelas, que de certa maneira limita a população local desprovida de recursos terem acesso a área. Por exemplo, antes da colocação das cancelas pelos caminhos que dão acesso à praia de Macaneta, a população local tinha acesso livre a este lugar turístico. O cenário altera após a construção da Estrada Circular de Maputo e da ponte que foi colocada na estrada que dá acesso a praia de Macaneta, no distrito de Marracuene. A partir de então, quem quisesse entrar e usufruir das águas cristalinas que a praia de Macenta proporciona, teria que pagar uma taxa.

Tendo em conta que grande parte da população local é pobre, identificamos que a taxa cobrada pela empresa gestora da praia de Macaneta, passou a ser um limitante para que a população local fosse a praia. Podemos dizer que a taxa atualmente cobrada pela empresa gestora da praia de Macaneta contribui para a exclusão da população local. A comunidade de Marracuene, sobretudo, a que vive nas proximidades da praia de Macaneta, que tem a natureza como um bem de uso comum, passou a ser inibida de usufrui-lá, pois a mesma, foi apropriada e privatizada com vista a atender os interesses meramente capitalistas, os de acumulação privada da riqueza.

Neste caso, quem se beneficia com a instalação de cancelas no acesso a praia são as empresas e não as populações circunvizinhas. O que fica na praia de macaneta, é apenas o lixo trazido por turistas sul-africanos e alguns moçambicanos que vivem nas cidades de Maputo e Matola, respectivamente. Para a remoção deste lixo, tem havido algumas iniciativas lançadas por alguns ambientalistas como é o caso do ambientalista Carlos Serra. Através do "Operação Caco", ele tem mobilizado pessoas para a remoção de lixo nas praias sendo a de Macaneta uma delas.

Carlos Serra tem aproveitado este momento para conscientizar as pessoas sobre a importância de não sujar as praias. Nesse sentido, podemos perceber que esse turismo acaba influenciando a organização territorial do distrito, que antes tinha o acesso livre a área, e no entanto, passaram a serem controladas, e produziram uma nova dinâmica para o turismo da região. No entanto, essas mudanças de certa maneira ainda não trazem tantos benefícios para ao distrito como inicialmente planejava, pois grande parte das divisas não ficam no distrito como é possível observar no relato abaixo:

o que representa o Turismo para o Distrito de Marracuene? A maioria de nossos clientes e empresários são sul-africanos e chineses. $O$ ruim é que todos esses turistas pagam os gastos no país de origem e vem pouca coisa para o distrito. $O$ distrito não realiza cobranças fiscais. A atividade tributária 
esta sendo criada ainda. E os empresários de nossa região pagam os tributos em outras províncias porque nós aqui não temos como cobrar. Sobre o licenciamento para abertura dos estabelecimentos até duas estrelas e 10 camas vai para responsabilidades da província e depois já é de responsabilidade da nação. E para a execução da atividade turística eles fazem uma contribuição que pode ser mensal, trimestral, semestral ou anual dependendo do valor. As empresas de turismo que temos aqui a maioria dos proprietários são estrangeiros, mas os funcionários de Marracuene. E quando essas empresas vão requerer o licenciamento eles devem dizer quantos empregados terão, quantos são homens, mulheres e estrangeiros (Entrevistada I, Serviço Distrital de Atividades Econômicas de Marracuene, 17/10/2016).

Ao longo de nossas visitas ao distrito observamos que as práticas turísticas ainda encontram-se em uma fase inicial, pois o distrito apresenta um grande potencial que pode ser aproveitado tanto pela população local quanto pelo Estado, que antes de tudo, deve ter uma política voltada para o desenvolvimento dessa atividade. Em relação a dinâmica e a organização territorial do distrito identificamos que muitos artesãos que vivem no distrito dependem da venda de seus produtos para garantir seu sustento, o que acaba contribuindo para que eles negociem uma peça com um valor mais baixo do que aquele encontrado nos grandes comércios, pois em determinados casos toda a família depende dos recursos que o artesanato propicia, e a família está involucrada na produção.

Além disso, pesca é uma atividade importante para o distrito, pois, além de ser uma fonte de alimentação, gera empregos. Vale salientar que a pesca artesanal tem um destaque no país sendo caracterizada pela utilização de técnicas rudimentares e o uso de pequenas embarcações, uma realidade que pode ser identificada na figura 13.

Figura 13: Pesca Artesanal na Praia de Macaneta no distrito de Marracuene/Moçambique Fonte: GONÇALVES, K. B. (2016).

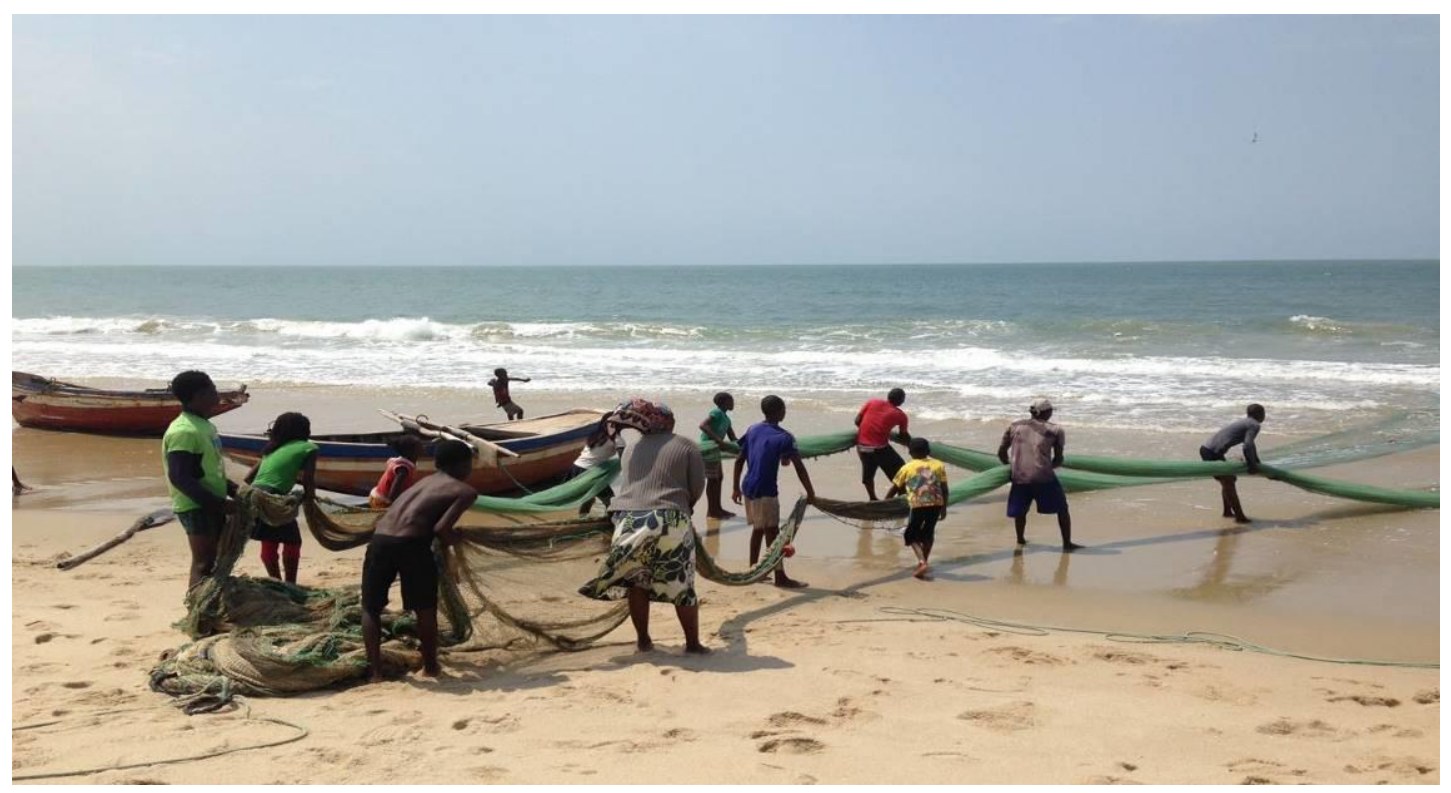


A pequena vivência em Marracuene, proporcionou identificar que múltiplos referenciais, estão presentes nas atividades que são desenvolvidas no distrito, pois a todo momento, a população local se depara com a figura do outro, ou seja, com os turistas estrangeiros que possuem referenciais identitário distintos, e durante essa experiência ocorre um movimento de (re)definição de "deles" e dos "outros". O nosso olhar sobre a organização, as tradições, os costumes, os modos de vida permitiu elaborar um novo olhar sobre a realidade moçambicana. Partindo da experiência de Marracuene foi possível notar que o territorio moçambicano possui uma riqueza de referenciais que surgem com certas particularidades que podem estar ligadas a religião, a política bem como aos costumes e tradições.

Nesse sentido, podemos evidenciar a territorialidade moçambicana como relações cristalizadas entre os sujeitos, e destes com o seu lugar de vida. E esse sentimento de pertencimento, está presente em situações e práticas do dia-a-dia. Um aspecto interessante a ser ressaltado é que nos últimos anos tem ocorrido um processo migratório do campo para cidade no país, pois muitos moçambicanos que viviam no campo ou nas pequenas cidades começaram a migrar para as cidades em busca de oportunidades, e no momento em que eles migram, levam consigo os referenciais do seu território de origem, e tentam conciliar esses referenciais com as experiências territoriais do lugar de chegada, e isso acaba produzindo outras territorialidades e costumes, enfim outras formas de se adaptar ao novo território.

Tendo em vista esse aspecto concordamos com Lopes de Souza (2007) que ressalta a ocupação e apropriação do território é vista como algo gerador de raízes e identidades, pois um grupo não pode ser compreendido sem o seu território, no sentido que a identidade sociocultural das pessoas está ligada aos atributos do espaço concreto. Por conseguinte, ao analisarmos um determinado território, como por exemplo, o território moçambicano torna-se perceptível a presença de referenciais que podem ser tanto históricos quanto geográficos, e esses influenciam na construção da identidade.

Ao abordarmos a formação da identidade é preciso se ater ao fato de que ela pode ser tanto uma valoração simbólica como um processo de identificação no espaço. Nesse sentido é possível perceber que uma identidade é construída de acordo com as dinâmicas do território e as relações que são estabelecidas nele. Haesbaert (1999) aponta que a identidade territorial é um tipo de identidade que se expressa na relação de pertencimento de um grupo a partir da delimitação de uma escala territorial de referência identitária, e que esta é definida fundamentalmente através do território, ou seja, dentro de uma relação de apropriação.

Em vista disso, é possível observar que a identidade territorial engloba a identidade como um movimento que ora se "reinventa", ora passa por uma "adaptação" e isso se torna perceptível quando as relações são construídas por novos discursos e distintos sujeitos e relações. Outra característica importante na construção da identidade territorial é abordada por Bonnemaison (2002) onde ela leva o indivíduo a 
construir um apego com o território, em que ele se sente como parte integrante e atuante, sendo capaz de exprimir e representar a sua concepção de mundo.

Portanto, entendemos que a identidade territorial é construída pelas relações sociais e dessas com a dimensão espacial, material e simbólica da realidade. Logo, ela está em constante construção, pois os conflitos, as disputas e as ações das relações de poder acabam influenciando. Em vista disso, partimos da reflexão proposta por Haesbaert (2006) que toda relação de poder espacialmente medida é produtora de identidade, pois controla, distingue, classifica, exclui, separa e ao separar acaba nomeando e rotulando (e, portanto exclui) os indivíduos e os grupos sociais das relações dos territórios.

Por fim, as diversas vivências e os múltiplos referenciais que observamos em território moçambicano contribuem para que esse território seja formado por múltiplas territorialidades que contribuem para a construção de uma identidade no qual os laços e as características estejam presentes na construção identitária, na valorização do território. Nesse sentido a identidade moçambicana está pautada nos referenciais que estão presentes no território, e conforme a intensidade das relações acabam se adaptando as realidades vivenciadas.

\section{CONSIDERAÇÕES FINAIS}

Ao observarmos o distrito de Marracuene foi possível perceber e compreender o território como um produto e condição da vida em sociedade e em natureza, onde ocorrem constantes mudanças e transformações, continuidades e descontinuidades que podem ser materiais desde as grandes construções e obras de infraestrutura, até simbólicas, como a influencia na identidade, e a relação com o outro. Foi possível perceber ainda que o turismo em Marracuene tem se desenvolvido sem levar em consideração as especificidades locais, pois o que se nota é que toda a estrutura que está sendo criada/produzida para o desenvolvimento das atividades turísticas, está voltada para os interesses globais, chegando em alguns momentos a limitar o acesso da população local que tem sua identidade e seus referenciais pautados nesse território.

Diante disso, percebemos que o turismo em Marracuene tem contribuído para que novas dinâmicas territoriais passassem a serem criadas em Marracuene, pois as mudanças, as interações e as relações com o outro acabam modificando as relações resultando em novas formas de organização, produção e dominação do território. Nessa perspectiva, foi possível observar que as transformações que estão em curso em Marracuene, acabam sendo uma apropriação do espaço natural pelo capital estrangeiro para a sua acumulação ampliada em escala global. 
Este processo impõe um modo de produção completamente distinto à realidade da população local, o que acarreta uma mudança no ritmo de vida, nas relações e no próprio controle do território. Portanto, uma grande parte das transformações que estão ocorrendo no distrito é direcionada para atrair mais turistas, pois para que essa atividade possa crescer e se estruturar no país ela tem que atender aos requisitos do turista atual, que busca além de lugares exuberantes e lazer, comodidade. 


\section{REFERÊNCIAS}

BONNEMAISON, Jöel. Viagem em torno do território. In: CORRÊA, Roberto L. e ROSENDHAL, Zeny (orgs.). Geografia cultural: um século. EdUERJ, p.83-121, Rio de Janeiro 2002.

BRUNA, Natacha. Ambiente como novo veículo de usurpação de recursos em Moçambique: enfoque nos reassentamentos. In: Destaque Rural N 83. Obervatório do Meio Rural - OMR, Maputo, 2020.

CATSOSSA, Lucas Atanásio. Disputas territoriais entre o campesinato e o agronegócio no Corredor de Nacala em Moçambique. Tese (Doutorado em Geografia), UFGD, Dourados-MS, 2020.

CATSOSSA, Mavuto Atanásio. Exploração Florestal na Zona Tampão do Parque Nacional de Mágoè: Estudo de Caso Localidade de Nhabando, Distrito de Cahora Bassa. Dissertação (Mestrado em Gestão Ambiental), UniPúnguè, Tete, 2019.

COSTA, Everaldo Batista da. A concretude do fenômeno turismo e as cidades-patrimônio-mercadorias: uma abordagem geográfica. Editora: Livre Expresso, Rio de Janeiro, 2010.

FERNANDES, Bernardo Mançano. Entrando nos Territórios do Território. In: PAULINO, Eliane Tomiasi \& FABRINI, João Edmilson (Orgs). Campesinato e territórios em disputas, 1ạ edição, Editora Expressão Popular, p. 273-301, São Paulo, 2008.

HAESBAERT, Rogério. Identidades Territoriais. In: ROSENDAHL, Zeny; CORRÊA, Roberto Lobato. Manifestações da Cultura no Espaço. Rio de Janeiro: EdUERJ, 1999.

HARVEY, David. A produção capitalista do espaço. Tradução: Carlos Szlak. 1a edição; Editora: Annablume, São Paulo, 2005

GONÇALVES, Karoline Batista. Pantanal Transfronteiriço (Bolívia-Brasil-Paraguai) e as Áreas Protegidas: Da produção de territórios as iniciativas de conservação. Tese (Doutorado em Geografia), UFGD, Dourados-MS, 2019.

HAESBAERT, Rogério. O Mito da Desterritorialização: do "Fim dos Territórios" à Multiterritorialidade. 2. ed. Rio de Janeiro: Bertrand Brasil, 2006.

MULHAISSE, Raimundo Alberto. Áreas de conservação e terras comunitárias: a sobreposição territorial, contradições e conflitos sociais na Serra de Gorongosa. Tese (Doutoramento em Geografia), UP, Maputo, 2018.

SILVEIRA, Maria Laura. Da fetichização dos lugares à produção local do turismo. In: RODRIGUES, Adyr Balatreri (Org). Turismo modrrnidade e globalização. Editora: HUCITEC, p. 36-54, São Paulo, 1997.

LOPES DE SOUZA, Marcelo José Lopes de. 0 território: sobre espaço e poder, autonomia e desenvolvimento. In: CASTRO, Iná Elias; GOMES, Paulo César da C. e CORRÊA, Roberto L. (Org.). Geografia: Conceitos e Temas. 10 ed. Rio de Janeiro: Bertrand Brasil, 2007.

MINISTERIO DA ADMINISTRAÇÃO ESTATAL. Perfil do Distrito de Marracuene Província de Maputo. Serie: Perfis Distritais, 2005.

MOÇAMBIQUE. Plano Estratégico para o Desenvolvimento do Turismo em Moçambique (2016-2025). Maputo, 2015.

MOÇAMBIQUE. Direito do Uso e Aproveitamento de Terra. 2015. Portal do Governo de Moçambique. Disponível em: http://www.portaldogoverno.gov.mz/por/Cidadao/Informacao/Direito-do-Uso-e Aproveitamento-de-Terra. Acesso em: 11 de nov. de 2016 às $18 \mathrm{~h} 24 \mathrm{~min}$.

MORETTI, Edvaldo César. Turismo em assentamentos rurais e unidades de conservação: desobedecer, desordenar e desinventar as geografias em movimento. In: THOMAZ, Rosangêla Custódio Cortez; MARIANI, Milton Augusto Pasquotto \& MORETTI, Edvaldo César (Orgs). O Turismo rural e as territorialidades do campo e da cidade. Editora: UFMS, p. 11-31; Campo Grande, MS, 2012.

RAFFESTIN, Claude. A produção das estruturas territoriais e sua representação. In: SAQUET, Marcos Aurelio; SPOSITO, Eliseu Savério. Territórios e territorialidades: teorias, processos e conflitos. 2a ed. Rio de Janeiro: Consequência Editora, 2015.

SADER, Emir. África, o continente de todos. Carta Maior Blog do Emir, 2017. Disponível em:< http://www.cartamaior.com.br/?/Blog/Blog-do-Emir/africa-o-continente-de-todos/2/23676> Acesso em: 26 de fev.

SANTOS, Milton. Por uma outra globalização: o pensamento único a consciência universal. 23ä; Ed. Record; Rio de Janeiro, 2013. SP. Brasil. 2013.

SANTOS, Milton. Dinheiro e território. In: SANTOS, Milton \& BECKER, Bertha. K. (Orgs). Território, territórios: ensaios sobre o ordenamento territorial. 3a edição, Editora

Lamparina, Rio de Janeiro, 2011.

SAQUET, Marcos Aurelio. Estudos territoriais: os conceitos de território e territorialidade como orientações para uma pesquisa científica. In: FRAGA, Nilson Cesar (Org.). Territórios e Fronteiras: (Re) Arranjos e Perspectivas. Florianópolis: Insular, 2011.

SAQUET, Marcos Aurelio. Por uma Abordagem Territorial. In: SAQUET, Marcos Aurelio; SPOSITO, Eliseu Savério. Territórios e territorialidades: teorias, processos e conflitos. 2a ed. Rio de Janeiro: Consequência Editora, 2015. 